\title{
THE CHOICE OF THE RATIONAL TECHNOLOGY OF "DENTATRYHIN" GEL
}

\author{
V.S.Kucherenko, Sv.M.Kovalenko, I.I.Baranova \\ National University of Pharmacy \\ Key words: dentistry; gel; technology research; structural-mechanical properties
}

Particular attention when developing drugs is paid to the choice of the rational technology. The technological process is an important aspect affecting the quality and stability of a drug, and should consist of a system of interconnected and evidence-based operations. The effect of the active components of "Dentatryhin" gel (triclosan, aminocaproic acid and lavender oil) in the concentrations specified on the structural-mechanical and physicochemical properties of test samples of the gels based on Carbomer $934 P$ has been studied; it is important from the point of view of consumer and technological characteristics of the medicinal product. It has been proven that the combined gel "Dentatryhin" developed for treating gingivitis represents a structured system with moderate thixotropic properties and satisfactory consumer characteristics. The rational technology of a dental gel has been experimentally determined; it consists of several sequential steps such as preparing a gel base, first introducing the alcohol solutions of triclosan and lavender oil into it, and then an aqueous solution of aminocaproic acid with the subsequent homogenization.

One of the most common causes of periodontitis and tooth loss is gingivitis of different etiology. Distribution of inflammation to the mucous membrane of the alveolar portions in all teeth of the upper and lower jaws is characteristic for the generalized gingivitis process. Therefore, creation of new drugs for topical use with the antimicrobial, anti-inflammatory and hemostatic effect is needed for effective pharmacotherapy of gingivitis $[6,11,12,15-8]$.

The most rational dosage form for topical treatment of gingivitis is gel. Dental gels are very popular because they are easy to apply on the gingival tissue, they are well distributed and absorbed in the mucous membrane of the gingival tissue. This dosage form provides local and uniform release of active substances, creates their high therapeutic concentration in sites of their application without a significant increase of the drug level in the systemic circulation $[1,3,5,6]$.

Using the comprehensive studies the composition of a new drug - "Dentatryhin" gel with triclosan, aminocaproic acid and lavender oil to treat gingivitis has been developed [7-9]. It should be noted that the high therapeutic activity of the drug can be achieved only with the right combination of active components and the base. The composition of the drug should be grounded on the basis of scientific experiments on the choice of active substances and excipients, as well as their desired concentration $[4,5,10]$.

One of the most important factors affecting the quality and stability of the gel is also the technology of its production. The technological production process should consist of the rational planned system of interconnected processes, each technological operation must be substantiated.

The aim of our work is to choose and develop the rational technology of preparing a dental gel "Dentatryhin" in the laboratory and industrial conditions.

\section{Materials and Methods}

The study subjects were the samples of the gels based on Carbomer 934 P produced by "Lubrizol" company. The active substances were introduced in them in the concentrations chosen on the basis of the literature search and grounded due to biological and microbiological research, namely triclosan $-0.5 \%$, aminocaproic acid $-5.0 \%$, lavender oil $-0.5 \%[1,3,7-9,14]$. To develop pilot batches of "Dentatryhin" gel for treating gingivitis the ingredients were introduced under the laboratory conditions of its preparation proposed. The following samples were prepared: Sample No.1 (gel base + triclosan + lavender oil), Sample No.2 (gel base + lavender oil), Sample No.3 (gel base + aminocaproic acid), Sample No.4 ("Dentatryhin" gel with triclosan, aminocaproic acid, lavender oil, nipagin, Carbomer $934 \mathrm{P}$, sorbitol, sodium hydroxide, ethyl alcohol and purified water in its composition), Sample No.5 (gel base + triclosan).

The standard equipment required in the production of soft dosage forms was used. When developing the technology a MM-1000 mechanical stirrer of "BioSan" company (Latvia) was used. The structural-mechanical studies were performed on a "Brookfield DV-II + PRO" viscometer with a SC 4-21 rotary spindle (USA) at 15$25^{\circ} \mathrm{C}$ (according to the SPhU) [2]. The rheological parameter - mechanical stability (MS) - was calculated as the ratio of tensile strength to fracture $(\tau 1)$ to the value limit after fracture $(\tau 2)$. The $\mathrm{pH}$ values were determined potentiometrically using a "pH Meter Metrohm 744" device (Germany) [13].

\section{Results and Discussion}

In order to develop the rational technology the effect of each active ingredient on the structural-mechanical properties of the samples of the gel was studied. For an objective evaluation of the results the study of a 
Structural-mechanical, physical and chemical characteristics of the test sample of the gels

\begin{tabular}{|l|c|c|c|c|c|}
\hline \multicolumn{1}{|c|}{ Name, indicator } & \multicolumn{1}{|c|}{$\begin{array}{c}\text { Sample } \\
\text { No.1 }\end{array}$} & $\begin{array}{c}\text { Sample } \\
\text { No.2 }\end{array}$ & $\begin{array}{c}\text { Sample } \\
\text { No.3 }\end{array}$ & $\begin{array}{c}\text { Sample } \\
\text { No.4 }\end{array}$ & $\begin{array}{c}\text { Sample } \\
\text { No.5 }\end{array}$ \\
\hline Appearance & $\begin{array}{l}\text { Semitransparent } \\
\text { gel with the } \\
\text { odour of lavender } \\
\text { essential oil }\end{array}$ & $\begin{array}{l}\text { Semitransparent } \\
\text { gel with the } \\
\text { odour of lavender } \\
\text { essential oil }\end{array}$ & $\begin{array}{l}\text { Transparent gel } \\
\text { with little odour } \\
\text { of ethanol }\end{array}$ & $\begin{array}{l}\text { Transparent gel } \\
\text { with the odour of } \\
\text { lavender essential } \\
\text { oil }\end{array}$ & $\begin{array}{l}\text { Non-transparent } \\
\text { odourless gel }\end{array}$ \\
\hline $\mathrm{pH}$ & $6.22 \pm 0.02$ & $6.01 \pm 0.03$ & $6.65 \pm 0.01$ & $6.55 \pm 0.01$ & $6.45 \pm 0.02$ \\
\hline $\begin{array}{l}\text { Structural viscosity, } \\
\eta \mathrm{mPa} \cdot \mathrm{s} \text { at 20 rev/s }\end{array}$ & 10000 & 13000 & 11300 & 13100 & 13000 \\
\hline $\begin{array}{l}\text { Structural viscosity, } \\
\eta \mathrm{mPa} \cdot \mathrm{s} \text { at 35 rev/s }\end{array}$ & 6900 & 9000 & 7800 & 9200 & 10000 \\
\hline $\begin{array}{l}\text { Structural viscosity, } \\
\eta, \mathrm{mPa} \cdot \mathrm{s} \text { at } 100 \mathrm{rev} / \mathrm{s}\end{array}$ & 3900 & 4600 & 4900 & 4600 & 7850 \\
\hline $\mathrm{MS}$ & 1.01 & 1.10 & 1.01 & 1.05 & 1.46 \\
\hline
\end{tabular}

Note: $\mathrm{n}=5$.

number of structural-mechanical and physicochemical parameters was performed (Table 1).

As can be seen from the results of Table 1, all samples of gels under research had a high structural viscosity value at certain speeds of a gate mixer.

The effect of the active substances in certain concentrations on the structural-mechanical properties of the experimental samples of gels was studied. It is important in terms of consumer and technological characteristics. According to the results obtained the rheograms of the samples studied were constructed in the "shear rate - shear stress" coordinates. As can be seen from Fig., all samples of gels had the plastic type of flow, i.e. introduction of active substances and excipients had no effect on the change of the type of flow. Samples No.1-3 had the lowest levels of rheoparameters.
It is known that gel bases based on acrylic acid copolymers exhibit the best structural-mechanical properties at neutral and slightly alkaline $\mathrm{pH}[4,10]$. Since essential oils have the acidic $\mathrm{pH}$ value, Samples No.1 and 2, respectively, show low values of rheoparameters.

The presence of ethanol - the solvent of lavender oil and triclosan (due to the dielectric constant of the solvent) affects decrease of the rheoparameters [10]. As for Sample No.3, it is known that the chemical structure of aminocaproic acid allows it to act as an additional neutralizing agent (the presence of the amino groups). However, in this case, re-neutralization was observed, and it led to unfolding of the polymer macromolecule chains and decrease of the rheoparameters. The rheogram of the gel developed is intermediate between the rheograms of other samples of the gel, suggesting the

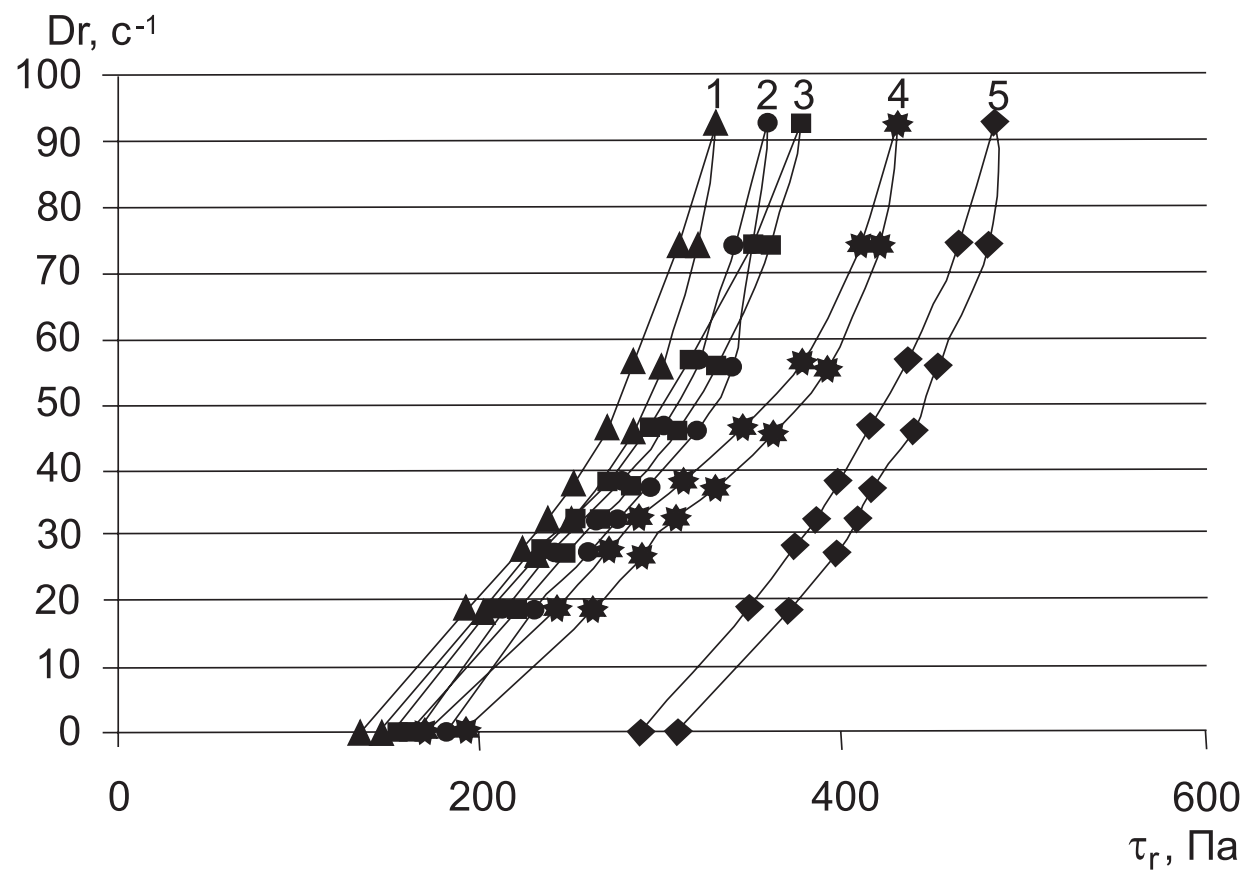

Fig. The rheogram of the samples of gels where: 1 - base + triclosan + lavender oil, 2 - base + lavender oil, 3 - base + aminocaproic acid, 4 - gel for treating gingivitis, 5 - base + triclosan. 
Table 2

The study of physical and chemical properties of "Dentatryhin" gel samples prepared by different technologies

\begin{tabular}{|l|c|c|}
\hline \multicolumn{1}{|c|}{ Name } & Technology No.1 & Technology No.2 \\
\hline Appearance & $\begin{array}{c}\text { Homogeneous semitransparent } \\
\text { gel-like mass without impurities }\end{array}$ & $\begin{array}{c}\text { Homogeneous semitransparent } \\
\text { gel-like mass without impurities }\end{array}$ \\
\hline $\mathrm{pH}(10 \%$ solution) & $6.55 \pm 0.01$ & $6.35 \pm 0.01$ \\
\hline Structural viscosity, $\mathrm{mPa} \cdot \mathrm{s}$ at $20 \mathrm{rev} / \mathrm{min}$ & 13100 & 15000 \\
\hline Structural viscosity, $\mathrm{mPa} \cdot \mathrm{s}$ at 35 rev/min & 9200 & 10000 \\
\hline Structural viscosity, $\mathrm{mPa} \cdot \mathrm{s}$ at 100 rev/min & 4600 & 4600 \\
\hline MS & 1.05 & 1.12 \\
\hline
\end{tabular}

Note: $\mathrm{n}=5$.

stability of the sample during storage. For a more complete study of the experimental samples, the MS values characterizing the degree of the structure destruction in the irreversible deformation process were calculated. The data obtained (Table 1) are confirmed by the calculated values of MS.

The samples of "Dentatryhin" gel were prepared at room temperature by two technologies given below.

Technology No.1. According to the classical scheme the gel base with Carbomer was prepared $[4,10]$. Then at the slow speed of a gate mixer (not more than $70 \mathrm{rev} / \mathrm{min}$ ) $70 \%$ of sorbitol solution was added to the gel base prepared. In parallel, lavender oil and triclosan were dissolved in ethanol, and then the transparent solution obtained was added to the gel base at slow speeds as well. The required number of aminocaproic acid was dissolved in the calculated amount of purified water and injected into the gel. Homogenization of the gel was carried out in a reactor with a gate mixer for 15 minutes while vacuuming to avoid the process of drug aeration.

Technology No.2. It differs by the fact that at first an aqueous solution of aminocaproic acid was introduced to the gel base obtained (gelation agent, sorbitol, preservative, purified water), and then the alcohol solution of triclosan and lavender oil. Homogenization of the gel was carried out in a reactor under the same conditions as in technology No.1. The data obtained are presented in Table 2.
As can be seen from Table 2, the sample prepared by technology No.1 has more alkaline $\mathrm{pH}$, providing a more stable gel system; it, in turn, is explained by forming the intermolecular bonds. As a result, a temporary net structure that prevents degradation of the sample is formed.

The mechanical strength of the sample prepared by technology No.2 is much more than in the sample prepared by technology No.1, it can create difficulties in the production process and poor consumer properties.

Thus, on the basis of the experiments conducted and the structural-mechanical properties studied technology No.1 was selected since the sample prepared by it had better structural-mechanical (MS close to perfect - 1.0, better extrusion properties) and technological properties.

CONCLUSIONS

Using the structural-mechanical and physicochemical research the effect of active substances of the gel (triclosan, aminocaproic acid and lavender oil) on stability of the gel base with Carbomer $934 \mathrm{P}$ has been studied.

The rational technology of a dental "Dentatryhin" gel has been selected; it comprises the following steps such as preparing a gel base; introduction of alcohol solutions of triclosan and lavender oil; introduction of the aqueous solution of aminocaproic acid to the gel base; homogenization of the gel; dispensing and packing of the gel.

\section{REFERENCES}

1. Безпала Ю.О. Перспективи використання карбомерів у технологї̈ гелів для лікування запальних захворювань слизової оболонки рота // Товарознавчі аспекти споживчих товарів: матер. II наук.-практ. конф. за міжнар. участю, м. Харків, 19 березня 2013 р. - Х.: НФаУ, 2013. - С. 71.

2. Державна фармакопея Украӥни / Держсавне підприємствово «Науково-експертний фармакопейний иентр». 1-е вид., 1 доп. - Х.: РІРЕГ, 2004. - 520 c.

3. Допоміжні речовини в технології ліків: вплив на технологічні, споживчі, економічні характеристики $i$ терапевтичну ефективність: навч. посіб. для студ. вищ. фармаи. навч. закл. / Авт.-уклад.: I.М.Периев, Д.І.Дмитрієвський, В.Д.Рибачук та ін.; за ред. І.М.Периева. - Х.: Золоті сторінки, 2010. - 600 с.

4. Козир Г.Р., Тихонов О.І. // Фармач. журн. - 2003. - №1. - С. 78-82.

5. Лебединець О.В., Баранова І.І., Петровська Л.С. // Укр. журн. клін. та лабораторної медицини. - 2010. - T. 5, №3. - C. 57-60.

6. Мюллер Х.П. Пародонтология. - Львов: Изд-во «ГалДент», 2004. - 256 c.

7. Портянко В.С., Коваленко Св.М., Малоштан Л.М. // Фармач. журн. - 2014. - №3. - С. 83-86. 
8. Портянко В.С., Коваленко Св.М., Стрілещь О.П. // Проблеми екологічної та медичноїгенетики і клінічної імунології. - 2012. - Вип. 5 (113). - С. 480-484.

9. Портянко В.С. Розробка складу гелю комплексної дї̈ для лікування гінгівіту // Матер. Всеукр. наук. конф. студентів та молодих учених «Актуальні питання створення нових лікарських засобів», м. Харків, 20-21 квітня 2011 р. - Х.: НФаУ, 2011. - С. 221-221.

10. Ролік С.М., Пімінов О.Ф, Лукієнко О.В. // Укр. журн. клін. та лабораторної медицини. - 2009. - Т. 4, №1. - C. 12-15.

11. Цепов Л.М. Заболевания пародонта: взгляд на проблему. - М.: МЕДпресс-информ, 2006. - С. 8-70.

12. Genco R. // J. Periodontol. - 2008. - Vol. 79, №8. - P. 1609-1611.

13. Malkin A.Ya. Rheology Concepts, Methods, and Applications. - London: Applied Science Publishers, 2006. $474 p$.

14. Muramatsu M., Kanada K., Nishida A. et al. // Intern. J. of Pharmac. - 2000. - Vol. 199, №1. - P. 77-83.

15. Offenbacher S., Barros S.P., Beck J.D. // J. Periodontol. - 2008. - Vol. 79, №8. - P. 1577-1584.

16. Picout D.R., Ross-Murphy S.B. // The Sci. World J. - 2003. - Vol. 24, №3. - P. 105-121.

17. Van Dyke T.E. // J. Periodontol. - 2008. - Vol. 79, №8. - P. 1601-1608.

18. Van Dyke T.E., Winkelhoff A.J. // J. Clin. Periodontol. - 2013. - Vol. 40, №14. - P. 1-7.

ВИБІР РАЦІОНАЛЬНОЇ ТЕХНОЛОГІЇ ГЕЛЮ «ДЕНТАТРИГІН»

В.С.Кучеренко, Св.М.Коваленко, І.І.Баранова

Ключові слова: стоматологія; гель; технологічні дослідження; структурно-механічні властивості

Особлива увага при розробці лікарських препаратів приділяється вибору раціональної технології. Технологічний процес - це важливий аспект, що впливає на якість і стабільність лікарського засобу, який повинен складатися з системи взаємопов'язаних та науково-обгрунтованих операцій. Вивчено вплив активних компонентів гелю «Дентатригін» (триклозану, амінокапронової кислоти і лавандової олії) у встановлених концентраціях на структурно-механічні та фрізико-хімічні властивості експериментальних зразків гелів на основі карбомера марки 934 P, що є важливим з точки зору споживчих і технологічних характеристик лікарського засобу. Доведено, що розроблений комбінований гель «Дентатригін» для лікування гінгівітів являє собою структуровану систему з помірними тиксотропними властивостями та задовільними споживчими характеристиками. Експериментально встановлена раціональна технологія стоматологічного гелю, яка складається з декількох послідовних операцій: приготування гелевої основи, введення в неї спочатку спиртових розчинів триклозану і лавандової олії, а потім водного розчину амінокапронової кислоти з подальшою гомогенізацією.

\section{ВЫБОР РАЦИОНАЛЬНОЙ ТЕХНОЛОГИИ ГЕЛЯ «ДЕНТАТРИГИН» \\ В.С.Кучеренко, Св.Н.Коваленко, И.И.Баранова}

Ключевые слова: стоматология; гель; технологические исследования; структурно-

механические свойства

Особое внимание при разработке лекарственных препаратов уделяется выбору рациональной технологии. Технологический процесс - это важный аспект, влияющий на качество и стабильность лекарственного средства, который должен состоять из системы взаимосвязанных и научно-обоснованных операций. Изучено влияние активных компонентов геля «Дентатригин» (триклозана, аминокапроновой кислоты и лавандового масла) в установленных концентрациях на структурно-механические и фризико-химические свойства экспериментальных образцов гелей на основе карбомера марки 934 P, что является важным с точки зрения потребительских и технологических характеристик лекарственного средства. Доказано, что разработанный комбинированный гель «Дентатригин» для лечения гингивитов представляет собой структурированную систему с умеренными тиксотропными свойствами и удовлетворительными потребительскими характеристиками. Экспериментально установлена рациональная технология стоматологического геля, которая состоит из нескольких последовательных операций: приготовления гелевой основы, введения в нее сначала спиртовых растворов триклозана и лавандового масла, а затем водного раствора аминокапроновой кислоты с последующей гомогенизацией. 